Irwan, A. W. • T. Nurmala • T.D. Nira

\title{
Pengaruh jarak tanam berbeda dan berbagai dosis pupuk kandang ayam terhadap pertumbuhan dan hasil tanaman hanjeli pulut (Coix lacryma-jobi L.) di dataran tinggi Punclut
}

\section{The effect of different plant spacing with various dosages of chicken manure on growth and yield of job's tears (Coix lacryma-jobi L.) on Punclut}

Diterima : 15 Februari 2017/Disetujui : 15 Maret 2017 / Dipublikasikan : 30 Maret 2017

CDepartment of Crop Science, Padjadjaran University

\begin{abstract}
The aim of this research was to observe the effects of different plant spacing and various dosage of chiken manure on growth and yield of job's tears in order to obtain one of plant spacing with dosage of chiken manure combination which gave the best effect on growth and yield of job's tears. The experiment was carried out from December 2015 to May 2016 at Punclut, with altitude about $1095 \mathrm{~m}$ above the sea level, Latosol type of soil, type $\mathrm{C}_{2}$ of rainfall according to Oldeman Classification. The experiment used Randomized Block Design (RBD) which consisted of nine treatments and repeated three times. The treatment were spacing $50 \times 50 \mathrm{~cm}+0$ ton/ha chiken manure, $50 \times 50 \mathrm{~cm}+1$ ton/ha, 50 $x 50 \mathrm{~cm}+2$ ton/ha, $75 \times 50 \mathrm{~cm}+0$ ton/ha, $75 \mathrm{x}$ $50 \mathrm{~cm}+1$ ton/ha, $75 \times 50 \mathrm{~cm}+2$ ton/ha, $100 \times 50$ $\mathrm{cm}+0$ ton/ha, $100 \times 50 \mathrm{~cm}+1$ ton/ha, and $100 \mathrm{x}$ $50 \mathrm{~cm}+2$ ton/ha. The results of the experiment showed that the treatment of different plant spacing and various dosages of chicken manure could affect the growth and the yield of job's tears. The treatment of spacing $75 \times 50 \mathrm{~cm}+2$ ton/ha chicken manure could improve grain weight per crop of job's tears.
\end{abstract}

Keywords : Plant spacing • Chicken manure • Job's tears

Sari Penelitian ini bertujuan untuk melihat bagaimana pengaruh jarak tanam yang berbeda dan berbagai dosis pupuk kandang ayam serta memperoleh salah satu kombinasi jarak tanam

\footnotetext{
Dikomunikasikan oleh Fiky Yulianto Wicaksono

Irwan, A. W.1 . T. Nurmala 1. T.D. Nira ${ }^{2}$

1 Staf Pengajar Dept. Budidaya Pertanian Fak. Pertanian

Unpad

2 Alumni Fakultas Pertanian Unpad

Korespondensi: aep_wawan_irwan@yahoo.co.id
}

dengan dosis pupuk kandang ayam yang memberikan pengaruh terbaik pada pertumbuhan dan hasil hanjeli pulut. Percobaan dilaksanakan dari bulan Desember 2015 sampai bulan Mei 2016 di Punclut, Lembang, Kabupaten Bandung dengan ketinggian tempat mencapai $1095 \mathrm{~m}$ di atas permukaan laut, dengan tanah Latosol dan tipe iklim C2 menurut klasifikasi Oldeman. Rancangan yang digunakan dalam penelitian ini adalah Rancangan Acak Kelompok (RAK) yang terdiri dari 9 perlakuan dan diulang sebanyak 3 kali, dengan perlakuan kombinasi jarak tanam $50 \times 50 \mathrm{~cm}+0$ ton/ha pupuk kandang ayam, $50 \times 50 \mathrm{~cm}+1$ ton/ha, $50 \times 50$ $\mathrm{cm}+2$ ton/ha, $75 \times 50 \mathrm{~cm}+0$ ton/ha, $75 \times 50 \mathrm{~cm}$ +1 ton/ha, $75 \times 50 \mathrm{~cm}+2$ ton/ha, $100 \times 50 \mathrm{~cm}+$ 0 ton/ha, $100 \times 50 \mathrm{~cm}+1$ ton/ha, dan $100 \times 50$ $\mathrm{cm}+2$ ton/ha. Hasil percobaan menunjukkan bahwa perlakuan jarak tanam berbeda dan pemberian berbagai dosis pupuk kandang ayam dapat mempengaruhi pertumbuhan dan hasil tanaman hanjeli pulut. Perlakuan jarak tanam 75 x $50 \mathrm{~cm}$ dan 2 ton/ha pupuk kandang ayam dapat meningkatkan bobot biji per rumpun tanaman hanjeli pulut.

Kata kunci: Jarak tanam • Pupuk kandang ayam - Hanjeli

\section{Pendahuluan \\ Penduduk Indonesia masih tergantung kepada beras sebagai pangan utamanya dan meru- pakan faktor utama pendorong terjadinya kerawanan pangan di Indonesia (lebih dari 90\%). Di sisi lain, produksi beras dalam negeri masih belum mampu memenuhi kebutuhan}


penduduk Indonesia yang setiap tahunnya terus meningkat. Tahun 2015, jumlah penduduk Indonesia meningkat sebesar 1,49\% dari tahun sebelumnya sedangkan produksi beras hanya meningkat 1,24\% (BPS, 2016). Konsumsi beras di Indonesia mencapai 135,20 kg/kapita/tahun jauh melebihi rata-rata tingkat konsumsi dunia yaitu $60 \mathrm{~kg} / \mathrm{kapita} /$ tahun (BPS, 2016). Salah satu upaya mengatasi masalah ketergantungan beras tersebut adalah pengembangan pangan lokal. Indonesia memiliki beragam tanaman penghasil sumber karbohidrat alternatif non beras yang berpotensi untuk pengembangan diversifikasi pangan lokal (Nurmala dkk., 2009). Tanaman serealia lokal yang potensial sebagai penghasil karbohidrat salah satunya adalah tanaman hanjeli (Coix lacryma-jobi L.).

Hanjeli merupakan tanaman serealia yang tidak hanya untuk pangan tetapi dapat dimanfaatkan juga sebagai pakan, obat dan bahan baku industri kerajinan (Nurmala, 2003). Tanaman ini merupakan tanaman penting setelah padi dan jagung di Indonesia dan beberapa kawasan seperti China bagian selatan (Duke, 1983). Hanjeli memiliki kandungan lemak, protein dan vitamin $B_{1}$ paling tinggi dibandingkan dengan serealia lain seperti beras, jagung, milet, sorgum dan barley (Grubben dan Partohardjono, 1996), selain itu hanjeli juga memiliki kandungan kalsium yang tinggi hampir setara dengan milet. Menurut Wu et al. (2007), kandungan lemak hanjeli paling tinggi yaitu sebesar $7 \%$.

Daerah asal hanjeli adalah Asia Tenggara termasuk Indonesia (Taylor, 1953). Di Indonesia banyak ditemukan di lahan hutan sebagai tanaman liar. Menurut Marco et al. (2012), hanjeli telah lama dikonsumsi sebagai sereal sehat bernutrisi di negara-negara Asia seperti China, Jepang, Philipina, Burma dan Thailand. Hanjeli masih kurang berkembang di Indonesia dikarenakan kurangnya pengetahuan dan minat petani tentang tanaman hanjeli. Umur tanaman yang panjang sekitar 5 - 6 bulan merupakan alasan kurangnya minat petani. Tanaman hanjeli khususnya di Jawa Barat masih dibudidayakan oleh masyarakat sebagai tanaman selingan di lahan marginal tanpa teknik budidaya yang intensif, tanpa pemupukan ataupun pemeliharaan lain (Nurmala, 2003). Oleh karena itu, pertumbuhan dan hasil tanaman hanjeli yang dihasilkan masih sangat rendah.

Teknik budidaya yang intensif ternyata diperlukan untuk meningkatkan pertumbuhan dan hasil tanaman. Potensi hasil hanjeli mencapai $4-6$ ton/ha biji berkulit atau $2-3$ ton/ha biji pecah kulit (Nurmala, 2015). PROSEA dan FAO melaporkan bahwa produktivitas hanjeli mencapai 2 - 4 ton/ha biji pecah kulit dengan presentase penggilingan (jumlah biji setelah pengupasan) sekitar $30-50 \%$.

Salah satu cara untuk mencapai produktivitas tersebut adalah pengaturan populasi tanaman dengan mengatur jarak tanam yang sesuai untuk tanaman hanjeli. Penggunaaan jarak tanam pada dasarnya adalah memberikan kemungkinan tanaman untuk tumbuh dengan baik tanpa mengalami banyak persaingan dalam hal mengambil air, unsur-unsur hara, dan cahaya matahari. Jarak tanam yang tepat penting untuk tanaman dalam memperoleh ruang tumbuh yang seimbang.

Beberapa hasil penelitian pada tanaman hanjeli menunjukkan bahwa penggunaan jarak tanam mampu meningkatkan bobot biji per hektar tanaman hanjeli dibandingkan dengan penanaman tradisional yang tidak memakai jarak tanam. Penelitian Vanny (2014), penggunaan jarak tanam $60 \times 50 \mathrm{~cm}$ menghasilkan biji 2,11 ton/ha. Penelitian Azka (2014) menunjukkan pada jarak tanam $80 \times 40 \mathrm{~cm}$ menghasilkan biji 4,28 ton/ha.

Faktor lain yang mendukung pertumbuhan dan hasil tanaman hanjeli selain pengaturan jarak tanam adalah peningkatan kesuburan tanah. Salah satu upaya dalam meningkatkan kesuburan tanah adalah dengan pemberian bahan organik yang dapat memperbaiki kemampuan tanah dalam menyimpan air, meningkatkan kapasitas infiltrasi, memperbaiki drainase tanah dan meningkatkan produktivitas tanah (Sutanto, 2002).

Pupuk kandang merupakan salah satu sumber bahan organik yang mudah didapat dan banyak tersedia disekitar petani. Pemberian pupuk kandang dapat meningkatkan serapan unsur hara oleh tanaman, mengurangi penggunaan dan meningkatkan efisiensi penggunaan pupuk kimia (Martin et al., 2006), dapat memperbaiki agregasi tanah sehingga mampu meningkatkan jumlah pori-pori tanah sehingga akhirnya menjadi media yang cocok bagi pertumbuhan tanaman karena jangkauan akar semakin luas sehingga penyerapan hara semakin mudah. Meluasnya jangkauan akar dan meningkatnya serapan hara diharapkan menaikkan efisiensi pemupukan sehingga tanaman dapat tumbuh dengan baik (Wahyuningsih, 
2005). Salah satu jenis pupuk kandang yang umum digunakan petani adalah pupuk kandang ayam. Umumnya petani lebih menyukai kotoran ayam karena kandungan N, P, K dan Ca lebih tinggi dibandingkan kotoran ternak lain (Setyorini, 2006).

Menurut Hartatik dan Widowati (2010), pupuk kandang ayam merupakan sumber yang baik bagi unsur-unsur hara makro dan mikro yang mampu meningkatkan kesuburan tanah serta menjadi substrat bagi mikroorganisme tanah dan meningkatkan aktivitas mikroba, sehingga lebih cepat terdekomposisi dan melepaskan hara. Kombinasi antara jarak tanam dan pupuk kandang dapat bersinergi untuk meningkatkan hasil tanaman hanjeli. Tanah yang semakin subur, maka pengaturan jarak tanam dapat dipersempit agar didapat populasi tanaman yang lebih banyak. Persaingan tanaman terhadap unsur hara menjadi lebih rendah karena tingkat kesuburan tanahnya lebih tinggi dengan adanya pupuk kandang ayam. Aplikasi pupuk kandang ayam juga diyakini memperbaiki sifat fisik tanah dan meningkatkan daur hara langsung pada akar tanaman sehingga mendorong pertumbuhan tanaman. Untuk itu diperlukan kombinasi yang tepat antara jarak tanam dan dosis pupuk kandang ayam. Tujuan penelitian ini adalah memperoleh jarak anam dan dosis pupuk kandang yang memberikan pengaruh terbaik terhadap pertumbuhan dan hasil tanaman hanjeli.

\section{Bahan dan Metode}

Penelitian ini dilaksanakan di Punclut, Kabupaten Lembang, Provinsi Jawa Barat. Percobaan dilakukan pada bulan Desember 2015 sampai dengan bulan Mei 2016.

Bahan yang digunakan dalam percobaan ini ialah benih hanjeli pulut Genotip 37 (benih dari koleksi Laboratorium Produksi dan Pemuliaan Tanaman Fakultas Pertanian Universitas Padjadjaran). Pupuk kotoran ayam dengan dosis 0 ton/ha, 1 ton/ha, dan 2 ton/ha, pupuk NPK majemuk 15:15:15, dan insektisida dan nematisida karbofuran. Peralatan yang digunakan dalam percobaan ini ialah alat-alat pertanian, alat ukur (penggaris/meteran), dan timbangan biasa dan digital, alat-alat laboratorium untuk analisa kimia, oven listrik, termometer, leaf area meter (untuk mengukur luas daun), fruit hardness tester (untuk mengukur kekerasan biji) dan alat tulis.

Metode penelitian yang digunakan adalah Rancangan Acak Kelompok (RAK), terdiri dari sembilan perlakuan yang diulang sebanyak tiga kali tiap perlakuan, sehingga terdapat 27 satuan percobaan. Perlakuan yang diberikan yaitu : $\mathrm{A}=$ Jarak tanam $50 \mathrm{~cm} \times 50 \mathrm{~cm}+0$ ton/ha; B = Jarak tanam $50 \mathrm{~cm} \times 50 \mathrm{~cm}+1$ ton/ha; $\mathrm{C}=$ Jarak tanam $50 \mathrm{~cm} \times 50 \mathrm{~cm}+2$ ton/ha; $\mathrm{D}=$ Jarak tanam $75 \mathrm{~cm} \times 50 \mathrm{~cm}+0$ ton $/$ ha; $\mathrm{E}=$ Jarak tanam $75 \mathrm{~cm} \times 50 \mathrm{~cm}+1$ ton/ha; $\mathrm{F}=$ Jarak tanam $75 \mathrm{~cm} \times 50 \mathrm{~cm}+2$ ton/ha; G = Jarak tanam $100 \mathrm{~cm} \times 50 \mathrm{~cm}+0$ ton/ha; $\mathrm{H}=$ Jarak tanam $100 \mathrm{~cm} \times 50 \mathrm{~cm}+1$ ton/ha dan I = Jarak tanam $100 \mathrm{~cm} \times 50 \mathrm{~cm}+2$ ton/ha.

Analisis data percobaan dilakukan berdasarkan model Rancangan Acak Kelompok. Uji Fischer pada taraf uji $5 \%$ dilakukan dengan menguji peluang dari variasi di antara nilai ratarata perlakuan dan bila berbeda nyata, dilanjutkan dengan uji gugus Scott-Knott pada taraf 5\% untuk menguji perbedaan antar masing-masing nilai rata-rata perlakuan.

Pengolahan lahan dilakukan satu minggu sebelum tanam dengan menggunakan cangkul, kemudian tanah dibuat petakan-petakan berukuran $4 \mathrm{~m} \times 2 \mathrm{~m}$ sebanyak 27 petak. Jarak antar ulangan $1 \mathrm{~m}$ dan jarak antar perlakuan 0,5 $\mathrm{m}$. Pupuk kandang ayam sebagai perlakuan diaplikasikan bersamaan dengan pengolahan lahan dengan cara dilarik secara merata sesuai dosis per petak perlakuan. Adapun dosis yang digunakan yaitu 0 ton/ha; 1 ton/ha dan 2 ton/ha. Pengaturan jarak tanam dilakukan dengan menggunakan meteran sesuai dengan perlakuan yaitu $50 \mathrm{~cm} \times 50 \mathrm{~cm} ; 75 \mathrm{~cm} \times 50 \mathrm{~cm}$ dan $100 \mathrm{~cm} \times 50 \mathrm{~cm}$.

Benih ditanam sesuai dengan masingmasing jarak tanam yang telah ditentukan. Lubang tanam dibuat menggunakan tugal dengan kedalaman 5,0 cm, lalu insektisida karbofuran ditaburkan ke dalam lubang lalu ditutup dengan tanah, kemudian memasukkan benih dengan jumlah tiga biji setiap polybag lalu di tutup dengan tanah. Pada saat umur 4 MST dilakukan penjarangan dan disisakan satu tanaman.

Pemberian pupuk NPK majemuk 15:15:15 dengan dosis $350 \mathrm{~kg} / \mathrm{ha}$. Pemberian pupuk NPK majemuk diberikan pada saat 1 mst dan pupuk susulan berupa urea sebanyak $200 \mathrm{~kg} / \mathrm{ha}$ pada 12 MST. 
Pemeliharaan tanaman hanjeli meliputi penyiraman, penyulaman, penyiangan gulma, pengendalian gulma, hama dan penyakit. Penyiraman dilakukan setiap hari apabila tidak turun hujan. Penyulaman dilakukan 21-24 hst. Penyiangan gulma dilakukan setiap ada yang tumbuh sepanjang percobaan penelitian dilaksanakan. Pengendalian gulma dilakukan secara mekanis dengan menggunakan tangan atau kored.

Hanjeli dipanen ketika tanaman telah mencapai matang fisiologis, yaitu sekitar 165 HST. Ciri-ciri tanaman hanjeli siap panen yang ditandai dengan biji yang telah berisi, keras apabila dipijit. Warna biji hanjeli setelah matang berwarna putih sampai coklat dan ungu. Pengamatan penunjang merupakan pengamatan yang digunakan untuk memperkuat dan memperjelas hasil percobaan serta untuk menunjang pengamatan utama. Pengamatan dalam percobaan ini meliputi pengamatan karakter kuantitatif dan kualitatif menggunakan semua tanaman hanjeli yang tumbuh. Komponen pertumbuhan meliputi tinggi tanaman (cm), jumlah daun, jumlah anakan per rumpun, jumlah srisip per rumpun, indeks luas daun (ILD), nisbah pupus akar (NPA) dan biomassa tanaman total. Komponen hasil meliputi jumlah malai per rumpun, jumlah biji per rumpun, bobot biji per rumpun (g), bobot 100 butir (g), rendemen biji pecah kulit (RBPK) (\%), kekerasan biji dan indeks panen.

\section{Hasil dan Pembahasan}

Tinggi Tanaman. Pengukuran tinggi tanaman hanjeli dilakukan pada saat tanaman berumur 3, 5, 7, 9, dan 11 MST. (dapat dilihat pada Tabel 1).

Berdasarkan hasil analisis data statistik pada Tabel 1 diketahui bahwa bahwa perlakuan jarak tanam dan pemberian pupuk kandang ayam berpengaruh nyata terhadap tinggi tanaman hanjeli pada 3, 5, dan 7 MST, sedangkan pada 9 dan 11 MST, perlakuan jarak tanam dan dosis pupuk kandang ayam menunjukan pengaruh yang tidak berbeda nyata terhadap tinggi tanaman hanjeli. Pada awal fase pertumbuhan, fotosintat yang dihasilkan tanaman lebih difokuskan pada pertumbuhan vegetatif tanaman, salah satunya adalah tinggi tanaman. Berdasarkan data terlihat adanya kecenderungan penambahan pupuk kandang ayam dapat menyebabkan pertambahan tinggi tanaman. Penambahan pupuk kandang ayam 1 ton/ha dan 2 ton/ha menghasilkan tanaman yang lebih tinggi dibandingkan dengan perlakuan tanpa penambahan pupuk kandang ayam.

Tabel 1. Pengaruh Jarak Tanam dan Dosis Pupuk Kandang Ayam Terhadap Tinggi Tanaman Hanjeli 3, 5, 7, 9 Dan 11 MST.

\begin{tabular}{cccccc}
\hline \hline Perlak & \multicolumn{5}{c}{ Tinggi Tanaman $(\mathrm{cm})$} \\
\cline { 2 - 6 } uan & $3 \mathrm{MST}$ & $5 \mathrm{MST}$ & $7 \mathrm{MST}$ & $9 \mathrm{MST}$ & $11 \mathrm{MST}$ \\
\hline $\mathrm{A}$ & $18,49 \mathrm{~b}$ & $39,28 \mathrm{~b}$ & $63,63 \mathrm{~b}$ & $92,83 \mathrm{a}$ & $144,33 \mathrm{a}$ \\
B & $18,80 \mathrm{~b}$ & $41,24 \mathrm{~b}$ & $69,67 \mathrm{~b}$ & $94,83 \mathrm{a}$ & $150,17 \mathrm{a}$ \\
$\mathrm{C}$ & $22,33 \mathrm{~b}$ & $42,82 \mathrm{~b}$ & $73,42 \mathrm{~b}$ & $97,58 \mathrm{a}$ & $157,67 \mathrm{a}$ \\
$\mathrm{D}$ & $18,30 \mathrm{~b}$ & $38,63 \mathrm{~b}$ & $60,37 \mathrm{~b}$ & $89,50 \mathrm{a}$ & $132,17 \mathrm{a}$ \\
E & $18,72 \mathrm{~b}$ & $38,79 \mathrm{~b}$ & $64,54 \mathrm{~b}$ & $92,37 \mathrm{a}$ & $138,83 \mathrm{a}$ \\
F & $20,25 \mathrm{~b}$ & $39,96 \mathrm{~b}$ & $69,42 \mathrm{~b}$ & $95,42 \mathrm{a}$ & $144,83 \mathrm{a}$ \\
G & $15,24 \mathrm{a}$ & $32,30 \mathrm{a}$ & $56,17 \mathrm{a}$ & $83,33 \mathrm{a}$ & $124,83 \mathrm{a}$ \\
H & $15,55 \mathrm{a}$ & $32,56 \mathrm{a}$ & $56,75 \mathrm{a}$ & $84,58 \mathrm{a}$ & $127,83 \mathrm{a}$ \\
I & $16,24 \mathrm{a}$ & $33,56 \mathrm{a}$ & $58,96 \mathrm{a}$ & $86,33 \mathrm{a}$ & $128,58 \mathrm{a}$ \\
\hline \hline
\end{tabular}

Keterangan : Angka-angka yang diikuti huruf yang sama pada setiap kolom yang sama tidak berbeda nyata menurut Uji Gugus Scott-Knott pada taraf 5\%

Pemberian pupuk kandang ayam dapat menambah unsur nitrogen. Kandungan nitrogen sangat berperan dalam pertumbuhan vegetatif tanaman. Tanaman dengan perlakuan pemberian pupuk kandang ayam 1 ton/ha atau 2 ton/ha mendapatkan unsur nitrogen lebih banyak dibandingkan tanaman tanpa pemberian pupuk kandang ayam. Tanaman tanpa pemberian pupuk kandang ayam hanya memanfaatkan unsur nitrogen yang ada di dalam tanah sedangkan kandungan nitrogen dalam tanah percobaan termasuk kriteria sedang yaitu $0,21 \%$. Berbeda dengan perlakuan pemberian pupuk kandang ayam yang mendapatkan nitrogen tambahan. Hasil analisis pupuk kandang ayam menunjukan kandungan $\mathrm{N}$ yang tergolong sangat tinggi yaitu $0,91 \%$. Unsur nitrogen mampu meningkatkan asam amino dalam tubuh tanaman yang berfungsi dalam pembelahan sel-sel pada jaringan meristem yang menyebabkan perpanjangan batang sehingga terjadi penambahan tinggi tanaman (Yelis, 2011).

Tinggi tanaman pada perlakuan jarak tanam $50 \times 50 \mathrm{~cm}$ berbeda nyata dengan perlakuan jarak tanam $100 \times 50 \mathrm{~cm}$ tetapi tidak berbeda nyata dengan jarak tanam $75 \times 50 \mathrm{~cm}$. Hal ini disebabkan bahwa jarak tanam rapat akan meningkatkan pertambahan tinggi tanaman karena adanya persaingan baik dalam 
unsur hara, air, dan sinar matahari, selain itu ruang yang dibutuhkan juga terlalu sempit sehingga tanaman tumbuh memanjang ke atas. Nursanti (2009) menyatakan bahwa pertambahan tinggi tanaman pada jarak tanam rapat disebabkan karena tajuk tanaman yang semakin merapat mengakibatkan kualitas cahaya yang diterima menjadi menurun. Semakin rapat jarak tanam yang dipakai maka pertumbuhan tinggi tanaman akan semakin cepat karena tanaman saling berusaha mencari sinar matahari yang lebih banyak.

Jumlah Daun. Pengamatan jumlah daun dilakukan pada tanaman hanjeli umur 3, 5, 7, 9, dan 11 MST.(dapat dilihat pada Tabel 2). Daun merupakan organ untuk proses fotosintesis pada tanaman.

Tabel 2. Pengaruh Jarak Tanam dan Dosis Pupuk Kandang Ayam Terhadap Jumlah Daun Tanaman Hanjeli 3, 5, 7, 9 Dan 11 MST.

\begin{tabular}{|c|c|c|c|c|c|}
\hline \multirow{2}{*}{$\begin{array}{c}\text { Perlak } \\
\text { uan }\end{array}$} & \multicolumn{5}{|c|}{ Jumlah Daun (helai) } \\
\hline & 3 MST 5 MST & $7 \mathrm{MST}$ & 9 MST & $11 \mathrm{MST}$ & 3 MST \\
\hline $\bar{A}$ & 1,92 a $\quad 6,17 \mathrm{a}$ & $17,08 \mathrm{a}$ & $40,92 \mathrm{a}$ & $79,17 \mathrm{a}$ & $1,92 \mathrm{a}$ \\
\hline B & 2,00 a $\quad 6,08 \mathrm{a}$ & $16,67 \mathrm{a}$ & $40,58 \mathrm{a}$ & $78,25 \mathrm{a}$ & $2,00 \mathrm{a}$ \\
\hline C & $2,25 \mathrm{a} \quad 6,33 \mathrm{a}$ & $16,83 \mathrm{a}$ & $40,92 \mathrm{a}$ & $79,92 \mathrm{a}$ & $2,25 \mathrm{a}$ \\
\hline D & 2,00 a $6,17 \mathrm{a}$ & $16,83 \mathrm{a}$ & $41,33 \mathrm{~b}$ & $80,50 \mathrm{~b}$ & $2,00 \mathrm{a}$ \\
\hline $\mathrm{E}$ & 2,08 a $\quad 6,25 a$ & $16,92 \mathrm{a}$ & $42,00 \mathrm{~b}$ & $80,83 \mathrm{~b}$ & $2,08 \mathrm{a}$ \\
\hline F & 2,33 a 6,25 a & $17,33 \mathrm{a}$ & $44,17 \mathrm{~b}$ & $84,67 \mathrm{~b}$ & $2,33 \mathrm{a}$ \\
\hline G & 2,17 a $\quad 6,33 a$ & $17,33 \mathrm{a}$ & $49,67 \mathrm{~b}$ & $94,50 \mathrm{~b}$ & $2,17 \mathrm{a}$ \\
\hline $\mathrm{H}$ & 2,25 a $\quad 6,50 a$ & $17,25 \mathrm{a}$ & $51,17 \mathrm{~b}$ & $99,92 \mathrm{~b}$ & $2,25 \mathrm{a}$ \\
\hline 1 & 2,50 a $6,42 a$ & $17,25 \mathrm{a}$ & $52,50 \mathrm{~b}$ & $101,08 \mathrm{~b}$ & $2,50 \mathrm{a}$ \\
\hline
\end{tabular}

Keterangan : Angka-angka yang diikuti huruf yang sama pada setiap kolom yang sama tidak berbeda nyata menurut Uji gugus Scott-Knott pada taraf 5\%

Perlakuan jarak tanam dan dosis pupuk kandang ayam terhadap jumlah daun tidak berpengaruh nyata pada fase awal pertumbuhan yaitu pada umur 3, 5, dan 7 MST, tetapi berpengaruh nyata pada umur 9 dan 11 MST, dimana perlakuan jarak tanam $100 \times 50 \mathrm{~cm}$ dengan berbagai dosis pupuk kandang ayam ( $G$, $\mathrm{H}$, I) berbeda nyata dengan semua perlakuan jarak tanam $50 \times 50 \mathrm{~cm}$ dengan berbagai dosis pupuk kandang ayam (A, B, C) tetapi tidak berbeda nyata dengan semua perlakuan jarak tanam $75 \times 50 \mathrm{~cm}(\mathrm{D}, \mathrm{E}, \mathrm{F})$.

Jumlah daun pada perlakuan jarak tanam yang lebih lebar $(100 \times 50 \mathrm{~cm})$ lebih banyak dibandingkan perlakuan jarak tanam sempit (50 $x 50 \mathrm{~cm}$ ) tetapi tidak berbeda nyata dengan perlakuan jarak tanam sedang $(75 \times 50 \mathrm{~cm})$. Menurut Pambayun (2008), jumlah daun dan jumlah cabang meningkat pada jarak tanam yang lebar dikarenakan kompetisi yang terjadi antar tanaman lebih rendah sehingga masingmasing tanaman mempunyai ruang tumbuh yang lebih besar dan tajuk dapat berkembang dengan baik.

Penambahan pupuk kandang ayam menaikkan jumlah daun meskipun tidak signifikan. Penambahan pupuk kandang ayam diasumsikan dengan penambahan unsur hara, salah satunya adalah nitrogen. Tresnawati (1999) menyatakan bahwa peningkatan pupuk nitrogen mengakibatkan penimbunan nitrat dalam daun yang mendorong pertumbuhan daun.

Jumlah Anakan per Rumpun. Hasil analisis sidik ragam mengenai jumlah anakan pada hanjeli umur 7, 9, dan 11 MST disajikan pada Tabel 3.

Tabel 3. Pengaruh Jarak Tanam dan Dosis Pupuk Kandang Ayam terhadap Jumlah Anakan Tanaman Hanjeli 7, 9 dan 11 MST.

\begin{tabular}{cccc}
\hline \hline \multirow{2}{*}{ Perlakuan } & \multicolumn{3}{c}{ Jumlah Anakan } \\
\cline { 2 - 4 } & 7 MST & 9 MST & 11 MST \\
\hline A & $4,08 \mathrm{a}$ & $10,25 \mathrm{a}$ & $13,17 \mathrm{a}$ \\
B & $4,17 \mathrm{a}$ & $10,08 \mathrm{a}$ & $13,00 \mathrm{a}$ \\
C & $4,25 \mathrm{a}$ & $10,25 \mathrm{a}$ & $13,33 \mathrm{a}$ \\
D & $4,17 \mathrm{a}$ & $10,33 \mathrm{~b}$ & $13,42 \mathrm{~b}$ \\
E & $4,25 \mathrm{a}$ & $10,33 \mathrm{~b}$ & $13,42 \mathrm{~b}$ \\
F & $4,33 \mathrm{a}$ & $10,92 \mathrm{~b}$ & $14,08 \mathrm{~b}$ \\
G & $4,33 \mathrm{a}$ & $12,50 \mathrm{~b}$ & $15,75 \mathrm{~b}$ \\
H & $4,42 \mathrm{a}$ & $13,50 \mathrm{~b}$ & $16,67 \mathrm{~b}$ \\
I & $4,50 \mathrm{a}$ & $13,25 \mathrm{~b}$ & $16,83 \mathrm{~b}$ \\
\hline \hline
\end{tabular}

Keterangan : Angka-angka yang diikuti huruf yang sama pada setiap kolom yang sama tidak berbeda nyata menurut Uji gugus Scott-Knott pada taraf 5\%

Pada 9 dan 11 MST, perlakuan jarak tanam $100 \times 50 \mathrm{~cm}$ dengan berbagai dosis pupuk kandang ayam $(G, H, I)$ berbeda nyata dengan semua perlakuan jarak tanam $50 \times 50 \mathrm{~cm}$ dengan berbagai dosis pupuk kandang ayam (A, B, C) tetapi tidak berbeda nyata dengan semua perlakuan jarak tanam $75 \times 50 \mathrm{~cm}(\mathrm{D}, \mathrm{E}, \mathrm{F})$.

Pada jarak tanam $50 \times 50 \mathrm{~cm}$ (populasi rapat) menghasilkan jumlah anakan yang lebih sedikit dibandingkan dengan perlakuan jarak tanam yang lebih lebar yaitu 75 x $50 \mathrm{~cm}$ dan 100 x $50 \mathrm{~cm}$. Hal ini sejalan dengan pernyataan Masdar dkk. (2006) yang menyatakan bahwa semakin rapat populasi tanaman, semakin sedikit jumlah anakan per rumpunnya, tanaman yang tumbuh pada jarak tanam rapat dapat mengakibatkan stres pada vigor sehingga perkembangan anakan terhambat. Husna (2010) menyatakan bahwa jarak tanam menentukan 
penyerapan radiasi matahari dan hara mineral. Pada jarak tanam lebar persaingan sinar matahari dan unsur hara sangat sedikit dibanding dengan jarak tanam yang rapat.

Jumlah Srisip per Rumpun. Hasil analisis sidik ragam mengenai jumlah srisip pada hanjeli umur 7, 9, dan 11 MST disajikan pada Tabel 4.

Tabel 4. Pengaruh Jarak Tanam dan Dosis Pupuk Kandang Ayam terhadap Jumlah Srisip Tanaman Hanjeli 7, 9 dan 11 MST

\begin{tabular}{cc}
\hline \hline Perlakuan & Jumlah Srisip \\
\hline A & $70,00 \mathrm{a}$ \\
B & $74,34 \mathrm{a}$ \\
C & $77,00 \mathrm{a}$ \\
D & $77,00 \mathrm{a}$ \\
E & $80,50 \mathrm{a}$ \\
F & $87,28 \mathrm{~b}$ \\
G & $92,67 \mathrm{~b}$ \\
H & $94,45 \mathrm{~b}$ \\
I & $99,00 \mathrm{~b}$ \\
\hline \hline
\end{tabular}

Keterangan : Angka-angka yang diikuti huruf yang sama pada setiap kolom yang sama tidak berbeda nyata menurut Uji gugus Scott-Knott pada taraf 5\%

Perlakuan jarak tanam 100 x $50 \mathrm{~cm}$ dengan berbagai dosis pupuk kandang ayam $(\mathrm{G}, \mathrm{H}, \mathrm{I})$ dan perlakuan jarak tanam $75 \times 50 \mathrm{~cm}+2$ ton/ha (F) berbeda nyata dengan semua perlakuan jarak tanam 50 × $50 \mathrm{~cm}$ dengan berbagai dosis pupuk kandang ayam $(\mathrm{A}, \mathrm{B}, \mathrm{C})$, perlakuan jarak tanam $75 \times 50 \mathrm{~cm}+0$ ton/ha (D), dan perlakuan jarak tanam $75 \times 50 \mathrm{~cm}+1$ ton/ha (E). Srisip yang dihasilkan pada perlakuan jarak tanam lebar $(100 \times 50 \mathrm{~cm})$ lebih banyak dibandingkan perlakuan jarak tanam yang lebih sempit $(50 \times 50 \mathrm{~cm})$. Hal ini diduga karena jumlah srisip berhubungan langsung dengan jumlah anakan, semakin banyak anakan produktif yang diproduksi semakin banyak srisip yang dihasilkan.

Indeks Luas Daun. Luas daun tanaman mencerminkan luas bagian yang melakukan fotosintesis, sedangkan indeks luas daun merupakan cerminan banyaknya cahaya matahari yang terserap oleh tanaman. Indeks luas daun (ILD) adalah perbandingan antara luas daun terhadap luas permukaan lahan yang menjadi tempat tumbuh suatu tanaman. Nilai ILD akan meningkat seiring dengan berkembangnya tanaman dan mencapai nilai maksimum pada saat awal masa generatif (Sitanggang dkk., 2006).
Perlakuan jarak tanam dan dosis pupuk kandang ayam berpengaruh nyata terhadap indeks luas daun ditunjukkan oleh data pada Tabel 5. Perlakuan semua jarak tanam 50 x $50 \mathrm{~cm}$ dengan berbagai dosis pupuk kandang ayam (A, B, C) berbeda nyata dengan semua perlakuan jarak tanam $100 \times 50 \mathrm{~cm}(\mathrm{G}, \mathrm{H}, \mathrm{I})$ dan semua perlakuan jarak tanam $75 \times 50 \mathrm{~cm}(\mathrm{D}, \mathrm{E}, \mathrm{F})$.

Tabel 5. Pengaruh Jarak Tanam dan Dosis Pupuk Kandang Ayam terhadap Indeks Luas Daun Tanaman Hanjeli 11 MST

\begin{tabular}{cc}
\hline \hline Perlakuan & ILD \\
\hline A & $4,24 \mathrm{a}$ \\
B & $3,40 \mathrm{a}$ \\
C & $4,20 \mathrm{a}$ \\
D & $4,75 \mathrm{a}$ \\
E & $4,91 \mathrm{a}$ \\
F & $4,67 \mathrm{a}$ \\
G & $6,16 \mathrm{~b}$ \\
H & $6,74 \mathrm{~b}$ \\
I & $7,15 \mathrm{~b}$ \\
\hline
\end{tabular}

Keterangan : Angka-angka yang diikuti huruf yang sama pada setiap kolom yang sama tidak berbeda nyata menurut Uji gugus Scott-Knott pada taraf $5 \%$

Berdasarkan data yang disajikan terlihat bahwa pada perlakuan jarak tanam lebih lebar $(75 \times 50 \mathrm{~cm}$ dan $100 \times 50 \mathrm{~cm})$ nilai ILD lebih besar jika dibandingkan dengan perlakuan jarak tanam yang lebih rapat yaitu $50 \times 50 \mathrm{~cm}$. Data menunjukan semakin lebar jarak tanam, semakin besar nilai indeks luas daunnya.

Penambahan dosis pupuk kandang ayam pada perlakuan semakin meningkatkan nilai ILD meskipun tidak signifikan. Pada perlakuan jarak tanam tanpa penambahan pupuk kandang ayam (A) memberikan hasil nilai ILD yang lebih kecil daripada perlakuan penambahan 1 ton/ha (B) dan 2 ton/ha pupuk kandang ayam (C). Hal ini sejalan dengan pernyataan Sitanggang dkk. (2006) yang menyatakan bahwa nilai ILD tergantung dari cara budidaya contohnya penggunaan jarak tanam, penggunaan jarak tanam rapat dengan pemberian nitrogen yang tinggi akan meningkatkan nilai ILD mencapai 10 atau lebih.

Menurut Lakitan (2010), produktivitas akan meningkat dengan meningkatnya ILD karena lebih banyak cahaya yang dapat ditangkap, tetapi nilai ILD yang terlalu tinggi tidak lagi meningkatkan produktivitas karena sebagian daun yang ternaung tidak melakukan fotosintesis secara optimal. 
Nisbah Pupus Akar. Berdasarkan hasil analisis data statistik pada Tabel 6 mengenai pengaruh perlakuan jarak tanam dan dosis pupuk kandang ayam terhadap nisbah pupus akar memberikan pengaruh yang berbeda nyata.

Tabel 6. Pengaruh Jarak Tanam dan Dosis Pupuk Kandang Ayam terhadap Biomassa Tanaman Total Tanaman Hanjeli

\begin{tabular}{ll}
\hline \hline \multicolumn{1}{c}{ Perlakuan } & NPA \\
\hline A & $4,94 \mathrm{~b}$ \\
B & $4,85 \mathrm{~b}$ \\
C & $4,66 \mathrm{~b}$ \\
D & $4,81 \mathrm{~b}$ \\
E & $4,79 \mathrm{~b}$ \\
F & $4,44 \mathrm{~b}$ \\
G & $6,91 \mathrm{a}$ \\
H & $5,42 \mathrm{~b}$ \\
I & $5,05 \mathrm{~b}$ \\
\hline \hline
\end{tabular}

Keterangan : Angka-angka yang diikuti huruf yang sama pada setiap kolom yang sama tidak berbeda nyata menurut Uji gugus Scott-Knott pada taraf 5\%

Berdasarkan hasil penelitian, nilai nisbah pupus akar berkisar antara 4,44-6,91. Nisbah pupus akar yang bernilai lebih dari satu menunjukkan pertumbuhan tanaman lebih ke arah pupus, sedangkan nisbah pupus akar yang bernilai kurang dari satu menunjukan pertumbuhan tanaman lebih ke arah akar.

Menurut Nurmala dan Irwan (2007), nisbah pupus akar yang ideal bagi tanaman pangan bernilai 3. Nilai nisbah pupus akar yang tinggi pada perlakuan jarak tanam $100 \times 50 \mathrm{~cm}+0$ ton/ha pupuk kandang ayam (G) diduga disebabkan oleh jarak tanam yang cukup lebar sehingga ruang tumbuh tanaman kearah pupus menjadi lebih luas. Pertumbuhan tanaman yang lebih difokuskan kearah pupus menyebabkan pembentukan akar terhambat.

Penyebab lain terhambatnya pembentukan akar diduga diakibatkan oleh tidak adanya penambahan pupuk kandang ayam sehingga tanaman tidak mendapatkan unsur hara yang cukup. Salah satu unsur yang berpengaruh terhadap perkembangan akar adalah unsur $\mathrm{P}$. Unsur $\mathrm{P}$ dapat merangsang pertumbuhan akar (root), yang selanjutnya berpengaruh pada pertumbuhan bagian di atas tanah (shoot). Winarso (2003) menyatakan bahwa tanaman yang ditanam pada lingkungan cukup $\mathrm{P}$ mempunyai distribusi perakaran yang baik dibandingkan dengan tanaman yang ditanam di lingkungan kekurangan unsur P. Kandungan P dalam tanah percobaan yang tergolong sangat rendah yaitu hanya 0,93 ppm. Salisbury and Ross (1995) menyatakan bahwa kandungan P yang rendah pada tanah mengakibatkan nilai nisbah pupus akar yang tinggi.

Biomassa Tanaman Total. Biomassa tanaman total mencerminkan pertumbuhan tanaman dan banyaknya unsur hara yang terserap per satuan bobot biomassa yang dihasilkan. Pengukuran biomassa tanaman dilakukan dengan cara menimbang bahan tanaman yang sudah dikeringkan pada suhu tertentu hingga mencapai berat yang konstan. Tabel 7 menunjukkan bahwa perlakuan jarak tanam dan dosis pupuk kandang ayam memberikan pengaruh nyata terhadap biomassa tanaman.

Tabel 7. Pengaruh Jarak Tanam dan Dosis Pupuk Kandang Ayam terhadap Biomassa Tanaman Total Tanaman Hanjeli

\begin{tabular}{cc}
\hline \hline Perlakuan & Biomassa Tanaman \\
\hline A & $717,31 \mathrm{a}$ \\
B & $709,73 \mathrm{a}$ \\
C & $830,14 \mathrm{a}$ \\
D & $839,35 \mathrm{a}$ \\
E & $836,73 \mathrm{a}$ \\
F & $937,37 \mathrm{~b}$ \\
G & $981,42 \mathrm{~b}$ \\
H & $1049,54 \mathrm{~b}$ \\
I & $1112,09 \mathrm{~b}$ \\
\hline \hline
\end{tabular}

Keterangan : Angka-angka yang diikuti huruf yang sama pada setiap kolom yang sama tidak berbeda nyata menurut Uji gugus Scott-Knott pada taraf 5\%

Perlakuan jarak tanam 100 × $50 \mathrm{~cm}$ dengan berbagai dosis pupuk kandang ayam (G, H, I) berbeda nyata dengan semua perlakuan jarak tanam $50 \times 50 \mathrm{~cm}$ dengan berbagai dosis pupuk kandang ayam (A, B, C), perlakuan jarak tanam $75 \times 50 \mathrm{~cm}+0$ ton/ha (D), dan perlakuan jarak tanam $75 \times 50 \mathrm{~cm}+1$ ton/ha (E) tetapi tidak berbeda nyata dengan perlakuan jarak tanam 75 $x 50 \mathrm{~cm}+2$ ton/ha (F).

Pada jarak tanam yang lebih lebar menghasilkan biomassa yang lebih besar dibandingkan dengan jarak tanam yang sempit. Hasil ini berkaitan dengan jumlah daun dan jumlah anakan. Pada jarak tanam yang lebih lebar, jumlah daun dan anakan lebih banyak sehingga biomassa tanaman yang dihasilkan lebih besar. Besarnya biomassa tanaman juga diduga berkaitan dengan nilai nisbah pupus akar. Sesuai dengan pernyataan Nurmala dan 
Irwan (2007) yang menyatakan bahwa nilai nisbah pupus akar yang tinggi disebabkan oleh pertumbuhan tanaman yang lebih difokuskan kearah pupus. Pada jarak tanam yang lebih lebar, nilai nisbah pupus akar tinggi karena pertumbuhan yang lebih fokus ke arah pupus sehingga biomassa yang dihasilkan tinggi.

Jumlah Malai per Rumpun. Perlakuan jarak tanam dan dosis pupuk kandang ayam berpengaruh nyata terhadap jumlah malai per rumpun (Tabel 8).

Tabel 8. Pengaruh Jarak Tanam dan Dosis Pupuk Kandang Ayam terhadap Jumlah Malai per Rumpun Tanaman Hanjeli

\begin{tabular}{cc}
\hline \hline Perlakuan & Jumlah Malai \\
\hline A & $553,33 \mathrm{a}$ \\
B & $561,33 \mathrm{a}$ \\
C & $622,67 \mathrm{a}$ \\
D & $576,00 \mathrm{a}$ \\
E & $644,00 \mathrm{a}$ \\
F & $698,22 \mathrm{~b}$ \\
G & $741,33 \mathrm{~b}$ \\
H & $755,56 \mathrm{~b}$ \\
I & $792,00 \mathrm{~b}$ \\
\hline
\end{tabular}

Keterangan : Angka-angka yang diikuti huruf yang sama pada setiap kolom yang sama tidak berbeda nyata menurut Uji gugus Scott-Knott pada taraf 5\%

Perlakuan jarak tanam $100 \times 50 \mathrm{~cm}$ dengan berbagai dosis pupuk kandang ayam $(\mathrm{G}, \mathrm{H}, \mathrm{I})$ berbeda nyata dengan semua perlakuan jarak tanam $50 \times 50 \mathrm{~cm}$ dengan berbagai dosis pupuk kandang ayam $(\mathrm{A}, \mathrm{B}, \mathrm{C})$, perlakuan jarak tanam $75 \times 50 \mathrm{~cm}+0$ ton/ha (D), dan perlakuan jarak tanam $75 \times 50 \mathrm{~cm}+1$ ton/ha (E) tetapi tidak berbeda nyata dengan perlakuan jarak tanam 75 $x 50 \mathrm{~cm}+2$ ton/ha (F).

Jumlah malai pada hasil percobaan menunjukan semakin lebar jarak tanam, semakin banyak jumlah malai yang dihasilkan. Hal ini antara lain karena pada jarak tanam lebar pertanaman lebih jarang atau populasinya lebih rendah dibandingkan jarak tanam rapat yang lebih banyak populasinya. Sesuai dengan pernyataan Mobasser et al. (2009), yang menyatakan bahwa pada jarak tanam rapat jumlah malai per rumpun menurun dengan meningkatnya kepadatan tanaman, tetapi jumlah malai per $\mathrm{m}^{2}$ nyata meningkat. Lebih lanjut menurut Maobe dkk. (2014), menyatakan bahwa jumlah malai berhubungan langsung dengan jumlah anakan, semakin banyak anakan produktif yang diproduksi semakin banyak malai yang dihasilkan.
Jumlah Biji per Rumpun dan Bobot biji per Rumpun. Perlakuan jarak tanam 50 × $50 \mathrm{~cm}$ dengan berbagai dosis pupuk kandang ayam (A, $B, C)$, berbeda nyata dengan perlakuan jarak tanam $75 \times 50 \mathrm{~cm}+2$ ton/ha $(\mathrm{F})$ dan semua perlakuan jarak tanam 100 × $50 \mathrm{~cm}$ dengan berbagai dosis pupuk kandang ayam (G, H, I) tetapi tidak berbeda nyata dengan perlakuan jarak tanam $75 \times 50 \mathrm{~cm}+0$ ton/ha (D) dan perlakuan jarak tanam $75 \times 50 \mathrm{~cm}+1$ ton/ha (E) (Tabel 9). Jumlah biji per rumpun hanjeli pada hasil percobaan berkisar antara 1659 - 2375 lebih besar dibandingkan deskripsi sebelumnya yang berkisar 1100 - 1500. Hal ini diduga dikarenakan perbedaan jarak tanam yang digunakan.

Tabel 9. Pengaruh Jarak Tanam dan Dosis Pupuk Kandang Ayam terhadap Jumlah Biji dan Bobot Biji per Rumpun Tanaman Hanjeli

\begin{tabular}{ccc}
\hline \hline Perlakuan & $\begin{array}{c}\text { Jumlah Biji } \\
\text { per Rumpun }\end{array}$ & $\begin{array}{c}\text { Bobot Biji per } \\
\text { Rumpun (g) }\end{array}$ \\
\hline A & $1659,78 \mathrm{a}$ & $197,46 \mathrm{a}$ \\
$\mathrm{B}$ & $1684,00 \mathrm{a}$ & $217,60 \mathrm{a}$ \\
$\mathrm{C}$ & $1868,11 \mathrm{a}$ & $234,29 \mathrm{a}$ \\
$\mathrm{D}$ & $1728,00 \mathrm{a}$ & $223,17 \mathrm{a}$ \\
$\mathrm{E}$ & $1932,33 \mathrm{a}$ & $238,16 \mathrm{a}$ \\
$\mathrm{F}$ & $2094,45 \mathrm{~b}$ & $268,13 \mathrm{~b}$ \\
$\mathrm{G}$ & $2224,00 \mathrm{~b}$ & $265,21 \mathrm{~b}$ \\
$\mathrm{H}$ & $2266,78 \mathrm{~b}$ & $274,93 \mathrm{~b}$ \\
I & $2375,89 \mathrm{~b}$ & $294,90 \mathrm{~b}$ \\
\hline \hline
\end{tabular}

$\overline{\text { Keterangan : Angka-angka yang diikuti huruf yang }}$ sama pada setiap kolom yang sama tidak berbeda nyata menurut Uji gugus Scott-Knott pada taraf 5\%

Data pada Tabel 9 dapat dilihat bahwa pada hasil percobaan menunjukan semakin lebar jarak tanam, semakin banyak jumlah biji per rumpun yangdihasilkan. Ali (2004) menjelaskan bahwa jarak tanam yang lebar dapat memberikan ruang tumbuh yang optimum sehingga biji yang terbentuk semakin banyak. Hal ini diduga karena besarnya ruang tumbuh untuk pertumbuhan malai sehingga menghasilkan jumlah biji yang banyak pula.

Populasi tanaman pada jarak tanam lebar dapat memanfaatkan radiasi surya lebih baik dibanding pada jarak tanam rapat terutama pada fase pengisian biji. Oleh sebab itu, hasil biji pada perlakuan jarak tanam lebar lebih tinggi dibandingkan dengan jarak tanam rapat. Syaban (1993) menyatakan bahwa jumlah dan bobot biji yang tinggi diakibatkan oleh banyaknya hasil fotosintesis yang diakumulasikan dalam organ tanaman yang nantinya akan dipakai untuk pengisian biji. Aktivitas metabolik pengisian biji 
harus bersamaan dengan aktivitas maksimum dari daun (source) dan daun dapat memelihara fotosintesis dengan baik selama pengisian biji untuk mencapai potensi hasil (Murchie et al. 2002).

Penambahan dosis pupuk kandang ayam berpengaruh dalam peningkatan jumlah biji per rumpun dan bobot biji per rumpun. Dosis pupuk kandang ayam yang semakin meningkat menyebabkan penumpukan asimilat yang tinggi. Menurut Gardner et al. (1991), bobot biji lebih dipengaruhi oleh pembagian asimilat selama pengisian biji. Penumpukan asimilat yang tinggi memerlukan wadah penyimpanan yang lebih banyak, oleh karena itu semakin tinggi dosis pupuk kandang ayam akan meningkatkan pula jumlah biji. Goldsworthy and Fisher (1992), menyatakan penyediaan nitrogen mempunyai pengaruh utama terhadap jumlah biji dan selanjutnya mempengaruhi hasil. Tanaman yang mengalami kekurangan nitrogen antara penanaman dan inisiasi hanya menghasilkan malai kecil dibanding tanaman yang memiliki persediaan nitrogen yang cukup.

Tabel 10. Pengaruh Jarak Tanam dan Dosis Pupuk Kandang Ayam terhadap Bobot Biji per Hektar Tanaman Hanjeli

\begin{tabular}{ccc}
\hline \hline Perlakuan & $\begin{array}{c}\text { Populasi Per } \\
\text { Hektar (tanaman) }\end{array}$ & $\begin{array}{c}\text { Bobot per } \\
\text { Hektar (ton) }\end{array}$ \\
\hline A & 32.000 & 6,32 \\
B & 32.000 & 6,96 \\
C & 32.000 & 7,50 \\
D & 21.337 & 4,69 \\
E & 21.337 & 5,00 \\
F & 21.337 & 5,63 \\
G & 16.000 & 4,24 \\
H & 16.000 & 4,40 \\
I & 16.000 & 4,72 \\
\hline \hline
\end{tabular}

Keterangan : Angka-angka yang diikuti huruf yang sama pada setiap kolom yang sama tidak berbeda nyata menurut Uji gugus Scott-Knott pada taraf 5\%

Bobot Biji per Hektar. Berdasarkan data pada Tabel 10 diketahui bahwa bobot biji per hektar perlakuan jarak tanam 50 × $50 \mathrm{~cm}$ memberikan hasil yang lebih besar dibandingkan dengan perlakuan jarak tanam $75 \times 50$ $\mathrm{cm}$ dan $100 \times 50 \mathrm{~cm}$ dengan dosis pupuk yang sama. Hal tersebut dikarenakan jumlah populasi jarak tanam $50 \quad$ x $50 \mathrm{~cm}$ lebih banyak dibandingkan dengan jumlah populasi jarak tanam $75 \times 50 \mathrm{~cm}$ dan $100 \times 50 \mathrm{~cm}$. Gardner et al. (1991) menyatakan bahwa jarak tanam berkorelasi dengan populasi atau jumlah tanaman per satuan luas, sehingga secara langsung ataupun tidak langsung akan berpengaruh terhadap hasil tanaman.

Muranyi (2015) menyatakan bahwa dengan mempersempit jarak antar tanaman akan menghasilkan hasil panen yang lebih tinggi. Widdicombe and Thelen (2002), mencatat bahwa hasil panen meningkat sampai 10\% dengan mempersempit jarak antar tanaman. Pada jarak tanam sempit populasi tanaman lebih banyak dibanding jarak tanam yang lebih lebar. Hasil panen meningkat seiring dengan meningkatnya populasi.

Bobot 100 Biji. Bobot 100 biji merupakan parameter yang menunjukkan besar endosperm pada biji. Endosperm adalah bagian terbesar dari biji yang merupakan tempat menyimpan cadangan makanan (Kusnadi, 2000).

Bobot 100 biji hanjeli pada hasil percobaan berkisar antara 11,90 g - 12,93 g sesuai dengan deskripsi sebelumnya yang berkisar 10,14 g 15,08 g. Data pada Tabel 13 menunjukkan bahwa perlakuan jarak tanam dan dosis pupuk kandang ayam memberikan pengaruh yang tidak nyata terhadap bobot 100 butir hanjeli. Hal tersebut menunjukan bahwa biji hanjeli memiliki ukuran yang hampir seragam sehingga berat biji tidak berbeda nyata sesuai dengan pernyataan Maobe dkk. (2014) yang melaporkan bahwa bahwa berat biji merupakan karakteristik setiap varietas tanaman.

Tabel 11. Pengaruh Jarak Tanam dan Dosis Pupuk Kandang Ayam terhadap Bobot biji per rumpun dan Bobot 100 biji Tanaman Hanjeli

\begin{tabular}{cc}
\hline \hline Perlakuan & Bobot 100 Biji (g) \\
\hline A & $11,90 \mathrm{a}$ \\
B & $12,93 \mathrm{a}$ \\
C & $12,60 \mathrm{a}$ \\
D & $12,87 \mathrm{a}$ \\
E & $12,33 \mathrm{a}$ \\
F & $12,63 \mathrm{a}$ \\
G & $11,93 \mathrm{a}$ \\
H & $12,20 \mathrm{a}$ \\
I & $12,43 \mathrm{a}$ \\
\hline \hline
\end{tabular}

Keterangan : Angka-angka yang diikuti huruf yang sama pada setiap kolom yang sama tidak berbeda nyata menurut Uji gugus Scott-Knott pada taraf 5\%

Tinggi rendahnya berat biji tergantung dari banyak atau tidaknya bahan kering yang terkandung dalam biji. Bahan kering dalam biji diperoleh dari hasil fotosintesis yang selanjutnya 
dapat digunakan untuk pengisian biji. Sesuai dengan pendapat Rahimi dkk. (2011) yang menyatakan bahwa rata-rata bobot biji sangat ditentukan oleh bentuk dan ukuran biji pada suatu varietas. Rahimi dkk. (2011) menambahkan apabila tidak terjadinya perbedaan pada ukuran biji maka yang berperan adalah faktor genetik.

Kekerasan Biji. Tingkat kekerasan biji berpengaruh terhadap kemudahan proses pemisahan kulit biji secara mekanis (Ginting dan Antarlina 1998). Kekerasan biji berpengaruh terhadap hasil bobot biji pecah kulit. Hal ini sesuai dengan pernyataan Murtini, dkk. (2005) pada penelitian gandum yang menyatakan bahwa bila berat biji pada gandum lebih besar maka kandungan endosperm tinggi dan tepung yang dihasilkan lebih banyak.

Kadar air diduga mempengaruhi kekerasan biji. Menurut BPPT (2009) kadar air pada biji dapat berpengaruh langsung terhadap proses degerminasi maupun terhadap pengujian kekerasan bijinya. Tingginya kadar air biji dapat menyebabkan lembaga (germ) mudah pecah dan lengket selama proses degerminasi. Kekerasan biji hanjeli setiap perlakuan (berkisar 16,43 s.d. $19,87 \mathrm{~kg} / \mathrm{cm}^{2}$ ) tidak menunjukkan perbedaan yang nyata diduga diakibatkan oleh kadar air yang sama sekitar $14 \%$. Proses dan waktu penjemuran yang sama mengakibatkan kadar air pada biji seragam.

Tabel 12. Pengaruh Jarak Tanam dan Dosis Pupuk Kandang Ayam terhadap Kekerasan Biji Tanaman Hanjeli

\begin{tabular}{cc}
\hline \hline Perlakuan & Kekerasan Biji $\left(\mathbf{k g} / \mathbf{c m}^{2}\right)$ \\
\hline A & $18,90 \mathrm{a}$ \\
B & $18,93 \mathrm{a}$ \\
C & $17,60 \mathrm{a}$ \\
D & $19,87 \mathrm{a}$ \\
E & $18,33 \mathrm{a}$ \\
F & $17,63 \mathrm{a}$ \\
G & $18,93 \mathrm{a}$ \\
H & $17,20 \mathrm{a}$ \\
I & $16,43 \mathrm{a}$ \\
\hline \hline
\end{tabular}

Keterangan : Angka-angka yang diikuti huruf yang sama pada setiap kolom yang sama tidak berbeda nyata menurut Uji gugus Scott-Knott pada taraf 5\%

Rendemen Biji Pecah Kulit (RBPK). Nilai RBPK menunjukkan hasil yang tidak berbeda nyata. Persentase rendemen biji pecah kulit yang tidak berbeda nyata diduga disebabkan oleh ukuran biji hanjeli yang seragam. Data hasil percobaan berkisar $51,20 \%-56,57 \%$.
Tabel 13. Pengaruh Jarak Tanam dan Dosis Pupuk Kandang Ayam terhadap Rendemen Biji Pecah Kulit (RBPK) Tanaman Hanjeli

\begin{tabular}{cc}
\hline \hline Perlakuan & RBPK (\%) \\
\hline A & $54,02 \mathrm{a}$ \\
B & $54,81 \mathrm{a}$ \\
C & $56,57 \mathrm{a}$ \\
D & $51,20 \mathrm{a}$ \\
E & $54,06 \mathrm{a}$ \\
F & $55,02 \mathrm{a}$ \\
G & $51,74 \mathrm{a}$ \\
H & $56,00 \mathrm{a}$ \\
I & $56,42 \mathrm{a}$ \\
\hline \hline
\end{tabular}

Keterangan : Angka-angka yang diikuti huruf yang sama pada setiap kolom yang sama tidak berbeda nyata menurut Uji gugus Scott-Knott pada taraf 5\%

Data Tabel 13 menunjukkan bahwa hampir setengahnya (lebih dari 50\%) biji hanjeli didapatkan setelah proses pemisahan dengan kulit biji. Hal tersebut sesuai dengan FAO (2014) yang melaporkan bahwa produksi hanjeli mencapai 2 - 4 ton/ha biji pecah kulit dengan presentase penggilingan (jumlah biji setelah pengupasan) sekitar $30-50 \%$.

Indeks Panen. Indeks panen adalah rasio hasil bobot kering biji dengan hasil bobot kering total tanaman. Perbandingan antara bobot kering organ hasil produksi dengan total bobot kering tanaman yang terbentuk menghasilkan nilai indeks panen.

Tabel 14. Pengaruh Jarak Tanam dan Dosis Pupuk Kandang Ayam terhadap Indeks Panen Tanaman Hanjeli

\begin{tabular}{cc}
\hline \hline Perlakuan & Indeks Panen \\
\hline A & $0,27 \mathrm{a}$ \\
B & $0,31 \mathrm{a}$ \\
C & $0,29 \mathrm{a}$ \\
D & $0,27 \mathrm{a}$ \\
E & $0,28 \mathrm{a}$ \\
F & $0,28 \mathrm{a}$ \\
G & $0,27 \mathrm{a}$ \\
H & $0,26 \mathrm{a}$ \\
I & $0,27 \mathrm{a}$ \\
\hline \hline
\end{tabular}

$\overline{\text { Keterangan : Angka-angka yang diikuti huruf yang }}$ sama pada setiap kolom yang sama tidak berbeda nyata menurut Uji gugus Scott-Knott pada taraf 5\%

Nilai indeks panen tanaman hanjeli setiap perlakuan tidak dipengaruhi oleh perlakuan jarak tanam dan dosis pupuk kandang ayam. Menurut Goldsworthy and Fisher (1992) nilai indeks panen optimal dapat bervariasi dari 0,15 sampai 0,52 dan nilai indeks panen dapat 
dipengaruhi oleh lama dan laju pertumbuhan; juga menunjukkan bahwa nilai indeks panen akan sangat bergantung pada lama dan laju pertumbuhan relatif sebelum dan setelah antesis (periode pembungaan), yang semua faktornya dipengaruhi oleh faktor genetik dan faktor lingkungan. Oleh karena itu, indeks panen tidak bisa dijadikan satu-satunya petunjuk yang dapat diandalkan untuk mengetahui hasil.

Nilai indeks panen hanjeli pada Tabel 14 yang masih rendah diduga dikarenakan fotosintat lebih dialokasikan ke arah pupus sehingga alokasi pada biji lebih rendah. Sejalan dengan pernyataan Gardner et al. (1991), tanaman yang mempunyai daun yang lebih luas pada awal pertumbuhan akan lebih cepat tumbuh, karena kemampuan fotosintat yang lebih besar memungkinkan membentuk seluruh organ vegetatif tanaman lebih besar yang kemudian menghasilkan produksi bahan kering yang semakin besar namun alokasi biji menjadi lebih sedikit.

\section{Kesimpulan dan Saran}

Berdasarkan hasil percobaan dapat disimpulkan sebagai berikut :

1. Pemberian kombinasi jarak tanam dan dosis pupuk kandang ayam memberikan pengaruh pada pertumbuhan dan hasil tanaman hanjeli pulut.

2. Perlakuan jarak tanam $75 \times 50 \mathrm{~cm}$ dengan penambahan 2 ton/ha pupuk kandang ayam dapat meningkatkan bobot biji per rumpun tanaman hanjeli pulut.

Saran pada percobaan ini adalah :

1. Perlu dilakukan percobaan lebih lanjut mengenai penggunaan dosis pupuk kandang ayam yang lebih besar untuk mengetahui sampai sejauh mana pupuk kandang ayam dapat mempengaruhi pertumbuhan dan hasil tanaman hanjeli pulut.

2. Jarak tanam yang digunakan pada percobaan belum optimal sehingga masih harus dilakukan percobaan menggunakan jarak tanam yang lebih sempit dan lebih lebar agar terlihat pertumbuhan dan hasil hanjeli yang optimal.

\section{Ucapan Terima Kasih}

Ucapan terima kasih disampaikan kepada Program ALG Universitas Padjadjaran, Kepala
Kebun dan Rumah Kaca Fakultas Pertanian Universitas Padjadjaran dan Mahasiswa Peminatan Pangan Departemen Budidaya Pertanian Fakultas Pertanian Universitas Padjadjaran.

\section{Daftar Pustaka}

Azka, M. 2014. Pengaruh Dosis Pupuk Kalium dan FMA terhadap Pertumbuhan dan Hasil Tanaman Hanjeli (Coix lacryma-jobi L.). Skripsi. Jurusan Budidaya Tanaman Fakultas Pertanian Unpad. Tidak Dipublikasikan.

Badan Pusat Statistik. 2016. Statistik Indonesia. Jakarta.

BPPT. 1983. Coix lacryma-jobi L. Hand Book of Energy Crops. Available online at : http://www.hort.purdue.edu/newcrop/d ukeenergy/Coixlacryma-jobi L.html. Diakses 13 November 2015.

BPPT. 2009. Program Pangan Karbohidrat. Tim Peneliti Bidang Pangan Pusat Teknologi Agroindustri. Badan Pengkajian dan Penerapan Teknologi. Jakarta.

FAO. 2014. Coix lacryma-jobi L. A Available online at : http://www.fao.org/ag/agp/agpc/doc/g base/data/pf000205.htm. Diakses tanggal 13 Juli 2016.

Gardner, F. P., R. B. Pearce dan R. L. Mitchell. 1991. Fisiologi Tanaman Budidaya. (terj). Jakarta : UI Press.

Goldsworthy and Fisher. 1992. Fisiologi Tanaman Budidaya. Tropik (terjemahan dari The Physiology of Tropical Field Crops oleh Tohari). Gadjah Mada University Press. Yogyakarta.

Grubben, G. J. H., and S. Partohardjono. 1996. Plant Resources of South - East Asia. Prosea. Bogor.

Hartatik, W. dan L.R. Widowati. 2010. Pupuk Kandang. http://www.balittanah.litbang. deptan.go.id. Diakses tanggal 25 September 2015.

Husna, Y. 2010. Pengaruh Penggunaan Jarak Tanam Terhadap Pertumbuhan dan Produksi Padi Sawah (Oryza sativa L.) Varietas IR 42 dengan Metode SRI (System of Rice Intensification). Jurnal. Jurusan Agroteknologi. Fakultas Pertanian. Universitas Riau. Vol 9 Hlm 2-7.

Kusnadi, M.H. 2000. Kamus Istilah Pertanian. Kanisius. Yogyakarta. 
Lakitan, Benyamin. 2010. Dasar-dasar Fisiologi Tumbuhan. Rajawali pers: Jakarta.

Maobe S.N., Martha K. Nyang'au, E.A. Basweti, A. Getabu, T.J. Mwangi and A.R. Ondicho. 2014. Effect of plant density on growth and grain yield of finger millet (Eleusine coracana) under high potential conditions of Southwest Kenya. World Journal of Agricultural Sciences 10 (6): 261-268.

Marco, K., Wunwisa, and Krasaekoopt. 2012. The use of job's tear (Coix lacryma-jobi L.) flour to substitute cake flour in butter cake. AU JT. 15 (4):233-238.

Masdar, Musliar K., Bujang R., Nurhajati H., dan Helmi. 2006. Tingkat Hasil dan Komponen Hasil Sistem Intensifikasi Padi (SRI) Tanpa Pupuk Organik di Daerah Curah Hujan Tinggi. Jurnal Ilmu Pertanian, Vol 8 (2): 126-131.

Mobassser, H. R., R. Yadi, M. Azizi, A. M. Ghanbari, and M. Samdaliri. 2009. Effect of density on morphological characteristics related-lodging on yield and yield components in varieties rice (Oryza sativa L.) in Iran. J. Agric. and Environ. Sci. 5(6):745-754.

Muranyi, E. 2015. Effect of plant density and row spacing on maize (Zea mays L.) grain yield in different crop year. Journal of Agricultural and Environmental Sciences.

Murchie, E.H., J. Yang, S. Hubbart, P. Horton, and S. Peng. 2002. Are there association between grain-filling rate and photosynthesis in the flag leaves of field growth rice. Journal of experimental Botany 53 (378).p.2217-2224.

Murtini, E. S. Susanto. T. Kusumawardani. R., 2005. Karakterisasi sifat fisik, kimia dan fungsional tepung gandum lokal varietas selayar, nias, dan dewata. J. Tek. Pert.. 6 (1): 57-64.

Nurmala, T. 2003. Serealia Sumber Karbohidrat Utama. PT Rineka Cipta Jakarta.

Nurmala, T. 2015. Eksplorasi dan Adaptasi Hanjeli (Coix lacryma-jobi $\quad$ L.) sebagai Pangan Bergizi dan Fungsional Mendukung Diversifikasi Pangan Berbasis Pangan Lokal. Seminar Guru Besar Faperta Unpad.

Nurmala, T., W.A. Qosim, dan Tj. S. Achyar. 2009. Eksplorasi, identifikasi, dan analisis keragaman plasmanutfah tanaman hanjeli (Coix lacryma-jobi L.) sebagai sumber bahan pangan berlemak di Jawa Barat. Laporan Penelitian Strategis Unpad.
Nurmala, T. dan Irwan A.W. 2007. Pangan Alternatif Berbasis Serealia Minor. Bandung. Penerbit : Pustaka Giratuna.

Nursanti, R. 2009. Pengaruh Umur Bibit dan Jarak Tanam Terhadap Pertumbuhan dan Produktivitas Tanaman Buru Hotong (Setaria italica (L.) Beauv). Skripsi. Program Studi Agronomi. Fakultas Pertanian. Institut Pertanian Bogor. Hal 27-28. Tidak dipublikasikan.

Pambayun, R. 2008. Pengaruh Jarak Tanam terhadap Produksi Beberapa Sayuran Indigenous. Skripsi. Program Studi Hortikultura. Fakultas Pertanian. Institut Pertanian Bogor. Tidak dipublikasikan.

Rahimi, Z. Zuhry, E. Nurbaiti. 2011. Pengaruh Jarak Tanam Terhadap Pertumbuhan dan Produksi Padi Sawah (Oryza sativa L.) Varietas Batang Piaman dengan Metode System of Rice Intensification (SRI) di Padang Marpoyan Pekanbaru. Jurnal. Fakultas Pertanian. Univ. Riau. Hlm. 7 - 13.

Salisbury, Frank B. and Cleon W Ross. 1995. Fisiologi Tumbuhan. Institut Teknologi Bandung. Bandung.

Setyorini, D. 2006. Pupuk Organik dan Pupuk Hayati. Balai Besar Sumberdaya Lahan Pertanian. Badan Litbang Pertanian. Bogor.

Sitanggang, G., Dirgahayu D., Carolita, I., Noviar H. 2006. Model spesial indeks luas daun (ILD) Padi menggunakan data TMLandsat untuk perdiksi produksi padi. Laporan Akhir Kegiatan Proyek Penelitian dan Pengembangan Pemanfaatan Pengolahan Data Penginderaan Jauh Satelit-LAPAN. Jakarta.

Sutanto, R. 2002. Pertanian Organik Menuju Pertanian Alternatif dan Berkelanjutan. Yogyakarta : Kanisius.

Syaban, R. A. 1993. Uji Pupuk P dan Pupuk Kandang Terhadap Pertumbuhan dan Hasil Kedelai (Glycine max (L.) Meeril). Departemen Pendidikan dan Kebudayaan RI. Universitas. Jember.

Taylor, G. D. 1953. Some Crop Distributions by Tribes in Upland Southeast Asia. Southwestern Journal of Anthropology.

Tresnawati, E. 1999. Pengaruh pemberian pupuk nitrogen dan tingkat populasi terhadap pertumbuhan dan produksi radiks kolesom (Talinum paniculatum Gaertn.). Warta Tumbuhan Obat Indonesia 5(4):7-8.

Vanny, T. 2014. Pengaruh Interval Waktu Pemupukan dengan Dosis NPK Majemuk 
terhadap Pertumbuhan dan Hasil Tanaman Hanjeli. Skripsi. Jurusan Budidaya Fakultas Pertanian Unpad. Tidak Dipublikasikan.

Wahyuningsih, H. 2005. Efisiensi pemupukan phospat pada alfisols dengan penambahan beberapa macam pupuk kandang dan tanaman kacang tanah (Arachis hypogaea L.) sebagai indikator. Surakarta.

Widdicombe D. W., Thelen D. K. (2002): Row width and plant density effects on corn grain production in the Northern Corn Belt. 94. (5.) 1020-1023.
Winarso, S. 2003. Kesuburan Tanah (Dasar Kesehatan dan Kualitas Tanah). Penerbit : Gaya Media.

Wu, T. T., Charles, A. L., and Huang, T. C. 2007. Determination of the contents of the main biological compounds of Adlay (Coix lacryma-jobi L.). Food Chem. 104: 15091515.

Yelis, R. 2011. Peningkatan Produktivitas Hanjeli Indigenous Kiara Payung sebagai Pangan Bergizi dengan Pemberian Pupuk N, P, K pada Dosis dan Waktu yang Berbeda. Skripsi. Jur. Budidaya Tanaman Fakultas Pertanian Unpad. Tidak dipulikasikan. 